The Role of Interfirm Transactions on Cross Border Integration in East Asia: A Case Study of Interlinkages between Busan in Korea and Fukuoka in Japan

\title{
THE ROLE OF INTERFIRM TRANSACTIONS ON CROSS BORDER INTEGRATION IN EAST ASIA: A CASE STUDY OF INTERLINKAGES BETWEEN BUSAN IN KOREA AND FUKUOKA IN JAPAN
}

\author{
Jonghyun Park ${ }^{{ }^{*}}$, Sohgen Boku ${ }^{* *}$ \\ "Hosei University, Faculty of Economics, Japan \\ "Pusan National University, Optical Mechatronics Research Center, Korea
}

\begin{abstract}
The purpose of this article is to discuss the inter-urban linkage between the non-capital cities in Korea and Japan, focusing on the relationships between Fukuoka and Busan, as part of an empirical research on the internationalization of non-capital cities in East Asia. We attempt to subdivide international trade activities of firms and analyze foreign destinations based on cities. The linkage between Busan and Fukuoka mainly sits at the apex of the international urban system, from the perspective of the gateway of "Physical Distribution" and "Business Trip"; however, links to Tokyo and Osaka mostly act as "Transaction" and functional cores such as sales channels. Fukuoka airport and Shimonoseki port have been utilized as a gateway. Fukuoka Airport has a promising evaluation concerning accessibility and convenience. Shimonoseki port has certain advantages due to the short time required for customs formalities, brevity of the shipping time and convenient daily shipping schedules.
\end{abstract}

Key words: cross border metropolis, international urban system, Busan, Fukuoka, Asia.

${ }^{1}$ Corresponding author: J. Park, Hosei University, Faculty of Economics, 2 Chome-17-1 Fujimi, Chiyoda, Tokyo 102-8160, Japan; e-mail: pakugen69@hosei.ac.jp 


\section{Introduction}

The purpose of this study is to discuss how non-capital cities in Asia can eradicate disparities and surmount contexts that they lagged behind respective national primary cities. As an example model of a transboundary economic cooperation in East Asia, the authors focused on the concept of Cross Border Metropolis between Busan and Fukuoka (CBM-BF), since both cities have been implementing major and minor joint cooperation projects in a lot of domains at local administrative level, for the long term. They are geographically and historically adjacent (Georgieva, 2016; Dimitrov, 2016; Park and Fujimura 2016).

Supported by the results of our research, the purpose of this paper is to discuss the idea of how important horizontal inter-urban linkages in the international urban system are. In this paper we have been extensively researching the inter-linkages between the non-capital cities in Korea and Japan, with focus on the relationships between Fukuoka and Busan, as a part of an empirical research of the internationalization of non-capital cities in East Asia.

Regionalization and globalization in various regions of the world since the 1980s, have encouraged adjacent border regions to seek feasibility and capacity of cross border integration and collaboration projects. Since the 1990s, various Asian countries have suggested the novel and innovative concept with regards to cross border cooperation (CBC). More specifically, the concept of Malaysia-Singapore Growth Triangle (the IMS-GT) was proposed in 1992 as a model of sub-regional economic co-operation in South-East Asia. The vast majority of those models have equivalent contexts in several aspects: (1) respective models have been driven by central governments and institutions; (2) most Asian countries have aspired to take initiatives for their respective countries in the main industries that would lead to economic growth, so that they initiated economic collaboration in growing and creative industries, such as IT, finance, fashion, design, automobile, etc. (Park and Fujimura 2016).

In this regard, it should be noteworthy that adjacent transboundary cities in East Asia, Busan and Fukuoka formalized the CBC in 2009, since both cities are non-capitals and are ranked second and sixth largest cities in Korea and Japan respectively and they formulated cooperation projects without the involvement of central governments. This became known as the concept of Cross Border Metropolis between Busan and Fukuoka or CBM-BF (Park and Fujimura 2016). 
The Role of Interfirm Transactions on Cross Border Integration in East Asia: A Case Study of Interlinkages between Busan in Korea and Fukuoka in Japan

Those contexts promoted this paper to discuss how the relationship between adjacent transboundary cities in East Asia have been forged by indigenous business activities. Therefore, as a case study, in this paper, we examine inter-urban relationships between Busan in South Korea and Fukuoka in Japan, focusing on international trade activities by the small and medium sized entrepreneurs located in Busan and their Japanese clients.

\section{Previous research}

The debate on urban systems in Japan as well as Korea have bred and continues to do so, dozens of empirical and theoretical studies (e.g. Abe 2005,2009,2010,2014; Kitada, 2000; Morikawa 1997; Murayama 1982, 1994; Nishihara 1991; Park 1997, 1998, 2002 Sugiura 1978, 1997). The internal urban structure has been examined as a node analysis whereas urban network or inter-urban linkages has been explored as a linkage analysis. They have focused on whether the urban system in national level is characterized by a hierarchical or non-hierarchical structure represented by Christarller's and Pred's models (Murayama 1994; Park 2002). In the previous studies, two mainstreams, consisting of business networks (e.g. intra-corporate branch or subsidiary networks) and interlinkages through flows (e.g. passengers, populations, information, etc.), have been emphasized. Especially, the spatial structures created by the internal organization and activities of business operations have played an essential determinant and encompassing urban system. Albeit in the tremendous previous literature the spatial structure of international urban systems and their mechanisms of formation have been acknowledged to recently be of paramount significance, they have been limited in the national, regional and local spatial level. In addition, the role of non-capital cities in peripheral regions and their globalization activities have received less attention, for the reason that the lack of a database representing the inter-linkages not in a state but at city level. In this regard, this paper aims to open a discussion on an empirical model that captures the status and the process of globalization of non-capital cities in international urban systems in East Asia, as a case study, choosing the inter-urban linkages between Fukuoka in Japan and Busan in Korea.

There are two main points in research. The first is the relationship between Fukuoka and Busan with regards to the frequency of international passengers, international telephone calls and international capital transactions. The second is the linkage between the two cities, founded on the stock data that is represented on the international transaction of firms. The data about 
transaction of firms consists of 3 kinds of transaction: (1) One is about trade activities of export and import, (2) the second is dependent on alliances between firms and (3) the third is built on intra-firm networks like branch and subsidiary networks. All of these had been researched in 1990'. Although the data goes back to 1990', the findings are very significant even today. Therefore, Author would like to present the inter-linkage between Busan and Fukuoka.

\section{Data and methods}

Firstly, we defined the economic territorial region of Fukuoka city as "Fukuoka" which consists of Fukuoka, Kitakyushu and Shimonoseki, following works of Abe (2014), Murayama (1982) and Park (1997). Murayama (1994) and Park (1998) also stated that the analyzed objects should be the cities within the international urban systems that are not defined as administrative districts but as a metropolitan area. Kagawa (1992) also defined those three cities as Northern Kyushu region with ports. Fukuoka is the capital city of Fukuoka Prefecture and is situated on the northern shore of the island of Kyushu in Japan. It is the most populous city in Kyushu, followed by Kitakyushu. As of 2011, Fukuoka is Japan's 6th largest city, having surpassed the population of Kyoto. This marks the first time that a city west of the Kinki region has a larger population than Kyoto since its founding in 794. Busan is South Korea's second largest metropolis after Seoul, with a population of approximately 3.6 million. It is also the largest port city in South Korea and the world's fifth busiest seaport by cargo tonnage. The city is located on the southeastern-most tip of the Korean peninsula.

There are no doubts that international trade geography made its greatest advances after 1990'. However, previous studies have been emphasizing relations between countries as study objects. Majority of authors, mainly tend to analyze port functions or physical distribution without paying sufficient attention to disparities between cities. They fail to explain the spatial structure of international trade from the viewpoint of international urban system. Therefore, this paper considers precisely the viewpoint above, the international urban system, focusing on the activities of exporters in Busan.

Furthermore, in the previous studies (Park 2002), we attempted to (1) define international trade between firms in three aspects, (2) adopt a methodology of international urban system and (3) examine the activities 
The Role of Interfirm Transactions on Cross Border Integration in East Asia: A Case Study of Interlinkages between Busan in Korea and Fukuoka in Japan

of exporters in Busan². The definition of international trade between firms, which the previous papers dealt with, was as follows: we focused on 3 aspects of trade activates that are listed as (1) "Transaction," (2) "Business trip" and (3) "Physical distribution"

Firstly, the aspect of "Transaction" represents contract behaviors between exporter and importer. The principal actors of international trade are the importers and exporters, and they can accomplish international businesses with contracts. Consequentially, they could create inter-linkages between cities and also form international urban systems. Thus, as a decisionmaking process, this aspect can be considered to play the most vital role in the international trade between trading firms.

Secondly, the aspect of "Business trip" indicates the international business trip of trading firms' staff members. It is necessary to make plenty of business trips to achieve business contract for the international trade. Since it believed to be very important in business we dedicated our attention to this aspect as well.

Lastly, the aspect of "Physical distribution" shows the decision- making process with focal point on the transportation routes. Based on the contracts resulted from the aforementioned two aspects, the international flow of transaction goods becomes also very important for this study.

In this paper, we analyzed the factors affecting the strong relationship between Fukuoka and Busan in the aspect of "Physical distribution". It will be examined what causes Fukuoka to be a stronghold of international flow.

This paper is based primarily on face-to-face semi-structured interviews with exporters located in Busan and their Japanese buyers. The data used in this paper is obtained by the field survey with interviews and questionnaire. The exporter in this study is defined as a small and medium sized business in the food and apparel sector, located in Busan. The main data sources used to explain trading features and attributes are the BUSAN Chiyok Suchul Hyonhwang (Directory of exporter in Busan) ${ }^{4}$.

\footnotetext{
${ }^{2}$ Concretely, author subdivided international trade activities of firms into 3 aspects and analyze foreign destinations based cities, rather than countries. This is one of the most unique features in this paper, compared to previous studies that have paid sufficient attention to relation between countries in international economics and management.

3 The spatial distribution of each aspect is examined in my previous papers. Having drawn feedback from them, the relationship between non-capital cities could be discussed.

${ }^{4}$ It was published by Busan Chamber of Commerce and Industry in 1994. These directorates contain information at firm level about the location of the firm, contact number, type of industry and exporting items and year of establishment in each place.
} 
The author conducted interviews at sample firms and public agencies related to trading with Japan, comparing 3 different periods of time: March 1995, May-July and Dec-Jan 1996. In addition, interviews with 14 companies which we had conducted were tracked in September and October in 2015. ${ }^{5}$

The reasons why we chose sample firms are as follows: According to BUSAN Chiyok Suchul Hyonhwang (exporter's directory in Busan), there were 868 firms trading with foreign countries, 335 of which traded with Japan. Stated as the industry sectors of exporting to Japan, all food businesses accounted for 78 firms, 66 of which were exporting to Japan. It means that at $85 \%$, food business has the highest level of dependence on exports to Japan. This is followed by apparel of 55 firms at $34 \%$ (Table 1). Therefore, food and apparel businesses are selected in this study.

Table 1.- Type of industry firms in Busan

\begin{tabular}{|l|c|c|c|c|c|}
\hline \multirow{2}{*}{ Industry } & \multicolumn{2}{|c|}{$\begin{array}{c}\text { number of trading } \\
\text { firms }\end{array}$} & \multicolumn{2}{c|}{$\begin{array}{c}\text { The number of } \\
\text { trading to Japan }\end{array}$} & (2)/(1) \\
\hline Food & 78 & $9 \%$ & 66 & $20 \%$ & $85 \%$ \\
\hline Apparel & 161 & $19 \%$ & 55 & $16 \%$ & $34 \%$ \\
\hline Shoes & 177 & $20 \%$ & 52 & $16 \%$ & $29 \%$ \\
\hline Fishing net & 14 & $2 \%$ & 1 & $0 \%$ & $7 \%$ \\
\hline Wooden goods & 5 & $1 \%$ & 3 & $1 \%$ & $60 \%$ \\
\hline Chemicals & 60 & $7 \%$ & 19 & $6 \%$ & $32 \%$ \\
\hline Rubber goods & 28 & $3 \%$ & 11 & $3 \%$ & $39 \%$ \\
\hline Nonmetallical goods & 6 & $1 \%$ & 2 & $1 \%$ & $33 \%$ \\
\hline Iron & 32 & $4 \%$ & 12 & $4 \%$ & $38 \%$ \\
\hline Metal & 70 & $8 \%$ & 17 & $5 \%$ & $24 \%$ \\
\hline Machinery & 72 & $8 \%$ & 23 & $7 \%$ & $32 \%$ \\
\hline Electrical goods & 43 & $5 \%$ & 12 & $4 \%$ & $28 \%$ \\
\hline Vessel & 17 & $2 \%$ & 8 & $2 \%$ & $47 \%$ \\
\hline
\end{tabular}

${ }^{5}$ Firstly, 123 sample firms were randomly selected and contacted in both the food and apparel sectors from the directory. author contacted each of them and requested an interview and questionnaire survey; 72 firms pledged to respond to the interview. After sending the questionnaires to the firms, author made a round to collect the questionnaires. Eventually, 62 interviews were conducted with managers trading with Japan. Interviews with exporters in Busan focused on (1) general outline of exporting business, relationship with their clients and employment structure, and (2) the number and the location of clients in Japan with the frequency of port or airport usage in both shipping of goods and going on business trips. 
The Role of Interfirm Transactions on Cross Border Integration in East Asia: A Case Study of Interlinkages between Busan in Korea and Fukuoka in Japan

\begin{tabular}{|l|c|c|c|c|c|}
\hline leisure goods & 38 & $4 \%$ & 22 & $7 \%$ & $58 \%$ \\
\hline Recreational goods & 22 & $3 \%$ & 8 & $2 \%$ & $36 \%$ \\
\hline the others & 45 & $5 \%$ & 24 & $7 \%$ & $53 \%$ \\
\hline
\end{tabular}

Source: Data base of "Directory of exporter in Busan" (1994)

Table 2 shows the size-structure of exporters in Busan. By looking at the number of employees and volume of export broken down by respective scale, we can realize that most of exporters operate not only small size businesses but also make contracts for small amounts of their products. The exporters with less than 100 employees occupied $90 \%$ in food business sector and $70 \%$ in apparel, respectively. Furthermore, the majority of exporters in Busan have less than 49 employees in food (82\%) and in apparel (58\%) business. In the case of volume of exports (Table $2 b$ ), the majority of exporters, which don't surpass 5 million dollars in annual exports, account for $79 \%$ of total sales amount in each business sector.

Table 2 - The size and structure of the exporters in Busan

\begin{tabular}{|c|c|c|c|c|c|c|}
\hline \multicolumn{7}{|c|}{ a. The number of employees } \\
\hline Number of employees & \multicolumn{2}{|c|}{ Food } & \multicolumn{2}{|c|}{ Apparel } & \multicolumn{2}{|c|}{ Total } \\
\hline $10-49$ & 31 & $82 \%$ & 14 & $58 \%$ & 45 & $73 \%$ \\
\hline $50-99$ & 4 & $11 \%$ & 3 & $13 \%$ & 7 & $11 \%$ \\
\hline $100-149$ & 1 & $2 \%$ & - & - & 1 & $2 \%$ \\
\hline 150-199 & - & - & 2 & $8 \%$ & 2 & $3 \%$ \\
\hline $200-$ & 2 & $5 \%$ & 5 & $21 \%$ & 7 & $11 \%$ \\
\hline Total & 38 & $100 \%$ & 24 & $100 \%$ & 62 & $100 \%$ \\
\hline \multicolumn{7}{|c|}{ b. The volume of export } \\
\hline Volume of export* & \multicolumn{2}{|c|}{ Food } & \multicolumn{2}{|c|}{ Apparel } & \multicolumn{2}{|c|}{ Total } \\
\hline $100-490$ & 30 & $79 \%$ & 19 & $79 \%$ & 49 & $79 \%$ \\
\hline $500-990$ & 6 & $16 \%$ & 3 & $13 \%$ & 9 & $15 \%$ \\
\hline $1000-1490$ & - & - & - & - & - & - \\
\hline $1500-1990$ & - & - & 1 & $4 \%$ & 1 & $2 \%$ \\
\hline $2000-$ & 2 & $5 \%$ & 1 & $4 \%$ & 3 & $5 \%$ \\
\hline Total & 38 & $100 \%$ & 24 & $100 \%$ & 62 & $100 \%$ \\
\hline *10,000US\$ & & & & & & \\
\hline
\end{tabular}

Source: based on the author's interviews 
Table 3 indicates the starting time of exporting and the number of clients in Japan. Most of exporters in Busan tend to export to Japan at the same time they started to operate international business. Their exporting activities to in Japan reached their peak around 1980s. Looking at each business sector, food businesses have a tendency of rising up gradually after commencing their business in 1970s whereas apparel businesses drastically rose up simultaneously, having started their business in 1980s. However, the number of clients in Japan displays similar trend between food and apparel business sector. More than $50 \%$ of exporters in Busan have only less than 4 clients, while exporters that keep business relationships with more than 10 clients are extremely few.

Table 3 - The starting time of exporting and the number of clients in Japan

\begin{tabular}{|c|c|c|c|c|c|c|c|c|c|c|c|c|}
\hline \multicolumn{13}{|c|}{ a. The starting time of exporting } \\
\hline \multirow{2}{*}{$\begin{array}{l}\text { Starting } \\
\text { time }\end{array}$} & \multicolumn{4}{|c|}{ Food } & \multicolumn{4}{|c|}{ Apparel } & \multicolumn{4}{|c|}{ Total } \\
\hline & \multicolumn{2}{|c|}{$\begin{array}{c}\text { to } \\
\text { overseas }\end{array}$} & \multicolumn{2}{|c|}{ to Japan } & \multicolumn{2}{|c|}{$\begin{array}{c}\text { to } \\
\text { overseas }\end{array}$} & \multicolumn{2}{|c|}{ to Japan } & \multicolumn{2}{|c|}{$\begin{array}{c}\text { to } \\
\text { overseas }\end{array}$} & \multicolumn{2}{|c|}{ to Japan } \\
\hline 1960-69 & 3 & $8 \%$ & 1 & $3 \%$ & 2 & $8 \%$ & 1 & $4 \%$ & 5 & $8 \%$ & 2 & $3 \%$ \\
\hline $1970-79$ & 9 & $24 \%$ & 8 & $22 \%$ & 3 & $13 \%$ & 2 & $16 \%$ & 12 & $19 \%$ & 10 & $16 \%$ \\
\hline $1980-89$ & 20 & $52 \%$ & 19 & $51 \%$ & 17 & $71 \%$ & 19 & $62 \%$ & 37 & $60 \%$ & 38 & $63 \%$ \\
\hline $1990-95$ & 6 & $16 \%$ & 9 & $24 \%$ & 2 & $8 \%$ & 2 & $18 \%$ & 8 & $13 \%$ & 11 & $18 \%$ \\
\hline Total & 38 & $100 \%$ & 37 & $100 \%$ & 24 & $100 \%$ & 24 & $100 \%$ & 62 & $100 \%$ & 61 & $100 \%$ \\
\hline \multicolumn{13}{|c|}{ b. The number of clients in Japan } \\
\hline $\begin{array}{l}\text { The } \\
\text { number } \\
\text { of clients }\end{array}$ & \multicolumn{4}{|c|}{ Food } & \multicolumn{4}{|c|}{ Apparel } & \multicolumn{4}{|c|}{ Total } \\
\hline $1-4$ & \multicolumn{2}{|c|}{20} & \multicolumn{2}{|c|}{$53 \%$} & \multicolumn{2}{|c|}{13} & \multicolumn{2}{|c|}{$54 \%$} & \multicolumn{2}{|c|}{33} & \multicolumn{2}{|c|}{$53 \%$} \\
\hline $5-9$ & \multicolumn{2}{|c|}{12} & \multicolumn{2}{|c|}{$32 \%$} & \multicolumn{2}{|c|}{6} & \multicolumn{2}{|c|}{$25 \%$} & \multicolumn{2}{|c|}{18} & \multicolumn{2}{|c|}{$29 \%$} \\
\hline $10-14$ & \multicolumn{2}{|c|}{5} & \multicolumn{2}{|c|}{$12 \%$} & \multicolumn{2}{|c|}{4} & \multicolumn{2}{|c|}{$18 \%$} & \multicolumn{2}{|c|}{9} & \multicolumn{2}{|c|}{$15 \%$} \\
\hline $15-$ & \multicolumn{2}{|c|}{1} & \multicolumn{2}{|c|}{$3 \%$} & & 1 & 3 & $\%$ & & 2 & & $\%$ \\
\hline Total & & 8 & & & & 24 & 10 & $0 \%$ & & 2 & & $0 \%$ \\
\hline
\end{tabular}

Source: based on the author's interviews 
The Role of Interfirm Transactions on Cross Border Integration in East Asia: A Case Study of Interlinkages between Busan in Korea and Fukuoka in Japan

\section{Results and discussion}

During the research authors interviewed both the exporter and importer as a case study, in order to identify the reasons why a lot of companies have shipped commodities to ports in Fukuoka Area.

First, we tried to track the entire routes of shipping commodities from storages of exporter in Busan to distribution center of importer in Japan. In addition, we have also calculated the amount of time and distribution costs, resulting from both exporter and importer choosing different routes, simulating the utilizing of ports in importer's proximity along the way: (1) What amount of costs are expected for distribution of commodities on entire shipping routes and (2) How much time it takes to get to the distribution center from exporter $\mathrm{B}$ to importer $\mathrm{C}$. The factors influencing inter-urban linkage as a gateway of physical distribution are as follows:

\section{Various costs in international physical distribution}

The costs of international physical distribution require trading companies to pay three kinds of fees for international shipping and delivery: (1) Domestic shipping fees in Korea, (2) International shipping fees from Busan to Japan and (3) Domestic shipping fees in ports of Japan.

Domestic shipping fees in Korea are composed of (1) trucking expenses from exporter's storage to Busan port, (2) terminal charges in Busan port and handling commodities and (3) customs duty. International shipping fees mostly consist of sea freight. Domestic shipping fees in Japan are comprised of (1) customs duty in Japan, (2) terminal charges in ports of Japan and (3) trucking fees from ports to distribution centers.

Exporters of cloths generally tend to make contracts with F.O.B (Free on Board) whereby importers pay international shipping fees and domestic shipping fees in ports of Japan. Contrary to that, exporters of foods are inclined to make contracts with C. I. F (Cost, Insurance and Freight) whereby importers shoulder only domestic shipping fees in ports in Japan. 


\section{A case study in food business}

a. The overview of transactions

We researched the transaction between the company DY ${ }^{6}$ in Busan and the SK in Tokyo, as a case study (Table 4) and investigated the entire route from DY to SK. First, products were shipped from Busan port by sea freight to ports in Japan. After landing the goods from the ship, all products were transported by trucking to the distribution center that is located at the Toyomi-district in Tokyo.

Table 4 -The distribuiton of transaction goods between DY in Busan and SK in Tokyo

\begin{tabular}{|c|c|c|c|c|c|}
\hline \multirow{2}{*}{$\begin{array}{l}\text { Means of } \\
\text { transportation }\end{array}$} & \multirow{2}{*}{$\begin{array}{c}\text { Shipping } \\
\text { dates from } \\
\text { Busan }\end{array}$} & \multirow{2}{*}{$\begin{array}{l}\text { Transaction } \\
\text { goods }\end{array}$} & \multirow{2}{*}{$\begin{array}{c}\text { Weight } \\
(\mathrm{Kg})\end{array}$} & \multicolumn{2}{|c|}{ Total sales (US\$) } \\
\hline & & & & US\$ & Unit price \\
\hline \multirow{11}{*}{$\begin{array}{l}\text { Sea freight } \\
\text { (Shimoseki port) }\end{array}$} & Mar 26 & Garfish & 1.140 & 6.612 & 5,80 \\
\hline & Sep 15 & & 4.000 & 24.000 & 6,00 \\
\hline & Feb 04 & Conger & 18.000 & 146.920 & 8,16 \\
\hline & Jun 21 & & 27.520 & 225.528 & 8,20 \\
\hline & Mar 25 & \multirow{6}{*}{ Ark shell } & 500 & 11.500 & 23,00 \\
\hline & Apr 08 & & 1.120 & 25.000 & 22,32 \\
\hline & Sep 29 & & 2.100 & 46.895 & 22,33 \\
\hline & Oct 20 & & 4.300 & 82.300 & 19,14 \\
\hline & Nov 01 & & 3.500 & 79.250 & 22,64 \\
\hline & Nov 24 & & 2.700 & 60.450 & 22,39 \\
\hline & Sep 02 & Manila clam & 13.500 & 54.000 & 4,00 \\
\hline $\begin{array}{l}\text { Airflight } \\
\text { (Sendai airport) }\end{array}$ & Sep 05 & Giant clam & 75 & 525 & 7,00 \\
\hline \multicolumn{3}{|l|}{ Total } & 78.455 & 762.980 & - \\
\hline
\end{tabular}

Source: based on the author's interviews

\section{$b$. The distribution routes of transaction goods}

We closely examined the advantage of Shimonoseki port regarding the total amount of time and distribution costs. Figure 1 and Table 5 show the

\footnotetext{
${ }^{6}$ Established in 1982 and located in Busan, DY has 56 employees and has been exporting processed marine products to Japan.
} 
The Role of Interfirm Transactions on Cross Border Integration in East Asia: A Case Study of Interlinkages between Busan in Korea and Fukuoka in Japan

total amount of time and the distribution costs in two possible scenarios that are taken for an actual route and hypothetical distribution route.

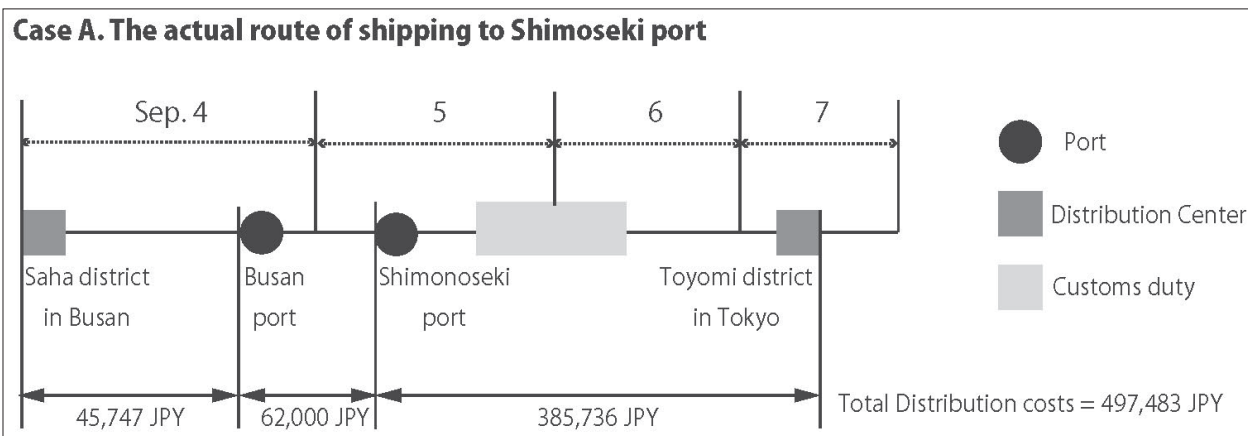

Case B. The hypothetical route of shipping to Yokohama port

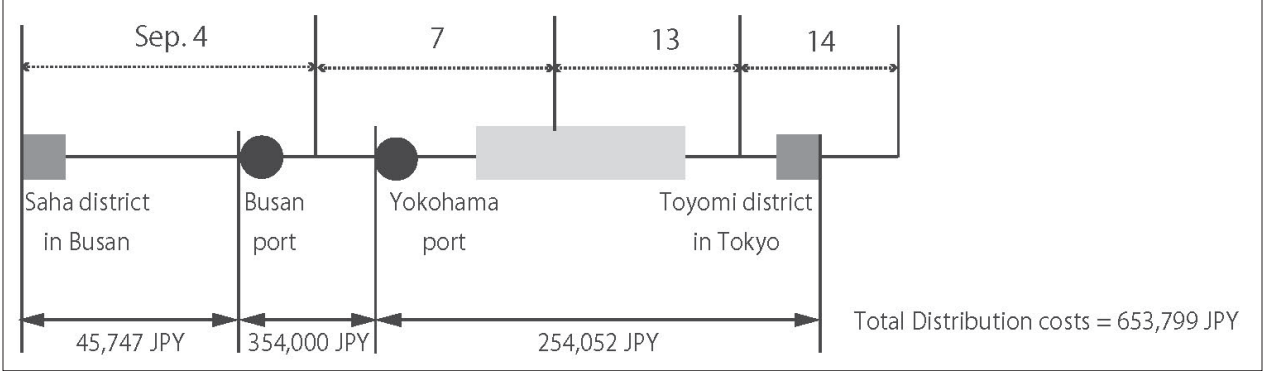

Figure 1 - The total amount of time and distribution costs in the cases of actual and hypothetical distribution routes Soure: The author' s interview

First, we compare the data for the total amount of time spent on shipping goods through Shimonoseki port, compared with other ports. After DY and SK made contracts, 13.5 tons of Manila clams were loaded from the DY's storage in Busan, delivered to Busan port, and headed for Shimonoseki port on Sep 4, 1995. They were unloaded in Shimonoseki port on the following day. Utilizing Shimonoseki port had an obvious advantage compared to other ports in Japan with respect to the total amount of time and distribution costs. It took almost a day to clear the goods through the customs, which means that the entire procedures had been completed on 6 Sep. It was on 8 Sep that goods finally arrived at the distribution center of SK. Therefore, it only takes 4 days for SK to get their goods to Tokyo. 
On the other hand, we assumed that the importer utilized the most immediate port from distribution center of SK, which is Yokohama port. The analysis showed the following: It was on 7 Sep that goods were completely unloaded in Yokohama port, after being shipped from Busan port. All customs' procedures were expected to finish on 13 Sep. Finally, it was estimated that the goods would be delivered on 14 Sep at distribution center of SK. From this, we could assume that it took 10 days in total for the merchandise to arrive to Japan from Busan.

Table 5 - The balance between actual and hypothetical distribution costs

\begin{tabular}{|c|c|c|c|c|}
\hline \multirow[b]{2}{*}{ Routes } & \multirow[b]{2}{*}{ Costs } & Actual costs & $\begin{array}{c}\text { Hypothetical } \\
\text { costs }\end{array}$ & \multirow[b]{2}{*}{ Balance } \\
\hline & & $\begin{array}{l}\text { (a) } \\
\text { Shimonoseki } \\
\text { port }\end{array}$ & $\begin{array}{c}\text { (b) } \\
\text { Yokohama } \\
\text { port }\end{array}$ & \\
\hline \multirow{3}{*}{$\begin{array}{l}\text { Domestic } \\
\text { flow in } \\
\text { Korea }\end{array}$} & Trucking fees & $¥ 11.616$ & $¥ 11.616$ & $¥-$ \\
\hline & Customs fees & $¥ 1.966$ & $¥ 1.966$ & $¥-$ \\
\hline & loading fees & $¥ 32.166$ & $¥ 32.166$ & $¥-$ \\
\hline $\begin{array}{l}\text { International } \\
\text { flow from } \\
\text { Busan to } \\
\text { Japan }\end{array}$ & (1) Sea frieght fees & $¥ 62.000$ & $¥ 354.000$ & $¥ 292.000$ \\
\hline \multirow{6}{*}{$\begin{array}{l}\text { Domestic } \\
\text { flow in Japan }\end{array}$} & $\begin{array}{l}\text { Unloading fees from } \\
\text { ships }\end{array}$ & $¥ 54.300$ & $¥ 54.300$ & $¥-$ \\
\hline & $\begin{array}{l}\text { Loading and } \\
\text { unloading fees to } \\
\text { custom storage }\end{array}$ & $¥ 59.400$ & $¥ 59.400$ & $¥-$ \\
\hline & Customs tariff & $¥ 41.800$ & $¥ 41.800$ & $¥-$ \\
\hline & (2) Trucking fees & $¥ 208.580$ & $¥ 35.000$ & $¥-173.580$ \\
\hline & $\begin{array}{l}\text { (3) Storage fees in } \\
\text { customs bonded zone }\end{array}$ & $¥ 16.200$ & $¥ 32.400$ & $¥ 16.200$ \\
\hline & (4) Taxes & $¥ 5.456$ & $¥ 31.152$ & $¥ 25.696$ \\
\hline \multicolumn{2}{|l|}{ Total } & $¥ 493.484$ & $¥ 653.800$ & $¥ 160.316$ \\
\hline
\end{tabular}

Source: based on the author's interviews

Next, we also examined the distribution costs of using Shimonoseki port in order to identify advantages of Shimonoseki port. Table 5 shows the total 
The Role of Interfirm Transactions on Cross Border Integration in East Asia: A Case Study of Interlinkages between Busan in Korea and Fukuoka in Japan

amount of distribution costs between DY and SK. It takes 493,483 JYP in total for both firms to distribute from Busan to Tokyo. Comparing the differences between actual and hypothetical distribution costs, it is easily state that transport fees and incidental fees can cause the disparity between actual and hypothetical distribution costs. Transport fees are comprised of two following costs: (1) the cost of utilizing sea freight to Shimonoseki port and Yokohama port, and (2) trucking fees to distribution center in Tokyo from Shimonoseki and Yokohama ports. Incidental fees indicate (3) a custom tariff and (4) storage fees in custom bonded zone.

Furthermore, we tried to simulate distribution costs, assigning DY and SK the most immediate port as the distribution center in Japan. Table 5 displays the disparity between the actual routes and hypothetical distribution routes. First, when DY and SK decided to use Shimonoseki port, the actual cost took in total of 292,236 JPY, consisting of transport fees of 270,580 JPY and incidental fees of 21,656 JPY. On the other hand, when it was assumed for both to designate the most proximate port as their primary destination, from the distribution center of SK, which is Yokohama port, the "hypothetical cost" could be estimated to take $452,552 \mathrm{JPY}$ that was made up of transport fees of 389,000 JPY and incidental fees of 63,552 JPY. The final difference between the actual cost and the hypothetical cost accounted for 160, 316JPY.

Likewise, it revealed that it had more advantages for both firms to ship the goods to Shimonoseki port, both in terms of the total amount of time and distribution costs.

\section{A case study in apparel business}

\section{a. The overview of transactions}

We conducted a case study of the contract among $\mathrm{CH}, \mathrm{CR}$ and $\mathrm{A}^{7}$. In 1995, they made transactions consisting of 46 items of women's garment that were shipped to Japan 17 times. We verified which kinds of ports and airports they had chosen and how many times each port and airport had been used for a year. Table 5 shows that they had also utilized ports rather than airports just as in the case of food trading explored in the previous case study. Finally, the number of times they shipped to Shimonoseki port takes a share of approximately $90 \%$ of the total amount of transactions (Table 6). It became apparent

${ }^{7} \mathrm{CH}$ was established in 1981 and located in Dongre-district in Busan, having 72 employees in 1995. $\mathrm{CH}$ has been exporting women's apparel to Japan. 
that the most active periods for delivery range from January to February and July to August. In general, stores started selling spring and summer collections in March, while fall and winter collections were mostly sold in September. This may indicate that A should focus on shipping their good in those seasons. All in all, goods in the case study were shipped to Shimonoseki port from Busan port. After unloading from Shimonoseki port, they were distributed by trucking services to distribution centers in Tokyo and Osaka respectively.

Table 6 -The volume of transaction goods between $\mathrm{CH}$ and $\mathrm{CR}$

\begin{tabular}{|c|c|c|c|c|c|}
\hline $\begin{array}{l}\text { Means of } \\
\text { transportation }\end{array}$ & $\begin{array}{l}\text { Shipping dates } \\
\text { from Busan }\end{array}$ & $\begin{array}{l}\text { Number of } \\
\text { shippings }\end{array}$ & $\begin{array}{c}\text { Number of } \\
\text { items }\end{array}$ & $\begin{array}{c}\text { Total sales } \\
\text { (US\$) }\end{array}$ & $(\%)$ \\
\hline \multirow{7}{*}{$\begin{array}{l}\text { Air flight } \\
\text { (Tokyo) }\end{array}$} & Jan. 21 & 3 & 2.265 & 21.840 & \multirow{7}{*}{$9,55 \%$} \\
\hline & Jan. 27 & 1 & 2.305 & 19.500 & \\
\hline & Jan. 29 & 1 & 202 & 1.818 & \\
\hline & Jan. 29 & 1 & 598 & 5.382 & \\
\hline & Feb. 5 & 1 & 370 & 4.551 & \\
\hline & Feb. 5 & 1 & 421 & 5.178 & \\
\hline & Feb. 9 & 1 & 57 & 701 & \\
\hline \multirow{12}{*}{$\begin{array}{l}\text { Sea frieght } \\
\text { (Shimonoseki) }\end{array}$} & Jan. 11 & 2 & 8.715 & 73.729 & \multirow{12}{*}{$90,45 \%$} \\
\hline & Feb. 19 & 1 & 340 & 4.080 & \\
\hline & Feb. 23 & 2 & 536 & 9.380 & \\
\hline & Jul. 27 & 1 & 1.977 & 24.119 & \\
\hline & Aug. 6 & 4 & 7.522 & 98.695 & \\
\hline & Aug. 12 & 10 & 25.153 & 237.170 & \\
\hline & Aug. 24 & 2 & 1.584 & 24.136 & \\
\hline & Sep. 1 & 6 & 1.734 & 23.303 & \\
\hline & Sep. 7 & 3 & 1.383 & 16.627 & \\
\hline & Sep. 18 & 3 & 1.419 & 15.929 & \\
\hline & Sep. 21 & 2 & 1.826 & 22.013 & \\
\hline & Sep. 25 & 1 & 575 & 9.200 & \\
\hline \multicolumn{2}{|l|}{ Total } & 46 & 58.982 & 617.351 & \\
\hline
\end{tabular}

Source: based on the author's interviews 
The Role of Interfirm Transactions on Cross Border Integration in East Asia: A Case Study of Interlinkages between Busan in Korea and Fukuoka in Japan

\section{b. The distribution routes of transaction goods}

We discovered the total amount of time and distribution costs required for the transactions using Shimonoseki port. In addition, we also tried to simulate the total amount of time and distribution costs, assuming that trading firms shipped the goods to immediate ports from distribution centers in Japan. Figure 2 and Table 7 display the differences between actual and hypothetical distribution routes, costs, and the total amount of time. $\mathrm{CH}$ shipped 7,512 pieces and 4 kinds of women's apparels to Japan through Shimonoseki port. Among those items, 3,802 pieces of goods were distributed to Osaka storage and the rest of 3,710 commodities were delivered to Tokyo distribution center that was located in suburban area, i.e. Saitama prefecture. All goods were shipped from Busan port on 6 Aug and unloaded on the next day in Shimonoseki port. All customs procedures were finished on $8 \mathrm{Aug}$. It was on 10 and $11 \mathrm{Aug}$ that all items arrived at Osaka and Tokyo distribution centers. Therefore, it took in total 4 and 5 days for the delivery to be completed in Osaka and Tokyo, respectively.

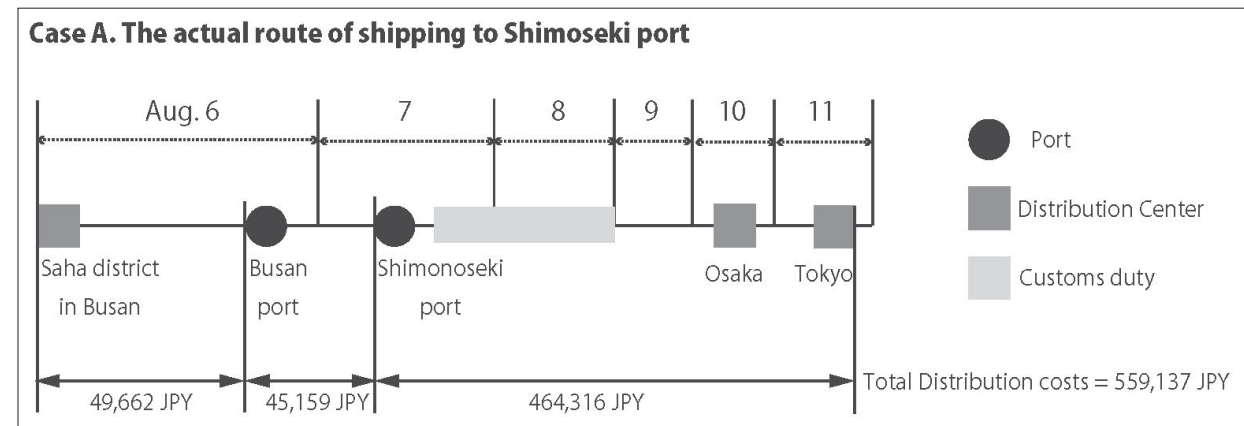

Case B. The hypothetical route of shipping to Yokohama and Kobe ports

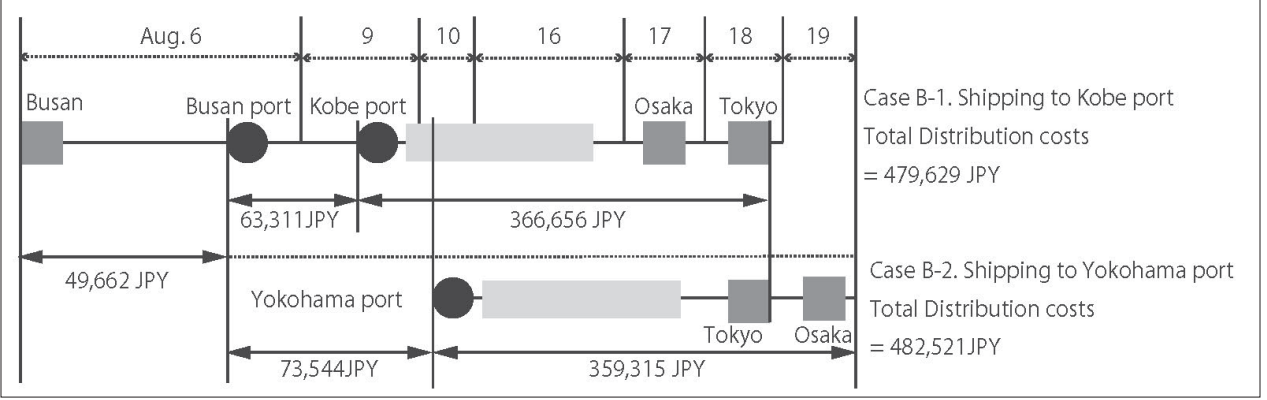

Figure 2 - The total amount of time and distribution costs in the case of apparel business transactions

Soure: The author's interview 
On the other hand, the results were different when the distribution of goods to Osaka and Tokyo were simulated, supposing they were headed for the most proximate ports. For the simulation, we used the hypothetical data of time and distribution costs necessary upon shipping goods from Busan port to a single port in Japan and delivering them to each of the distribution centers in Tokyo and Osaka.

Table 7 - The balance between actual and hypothetical distribution costs in apparel business

\begin{tabular}{|c|c|c|c|c|c|c|}
\hline \multirow[b]{2}{*}{ Routes } & \multirow[b]{2}{*}{ Costs } & \multirow{2}{*}{$\begin{array}{c}\text { Actual costs } \\
\text { (a) } \\
\text { Shimonoseki } \\
\text { port }\end{array}$} & \multicolumn{2}{|c|}{ Hypothetical costs } & \multicolumn{2}{|c|}{ Balance } \\
\hline & & & $\begin{array}{c}\text { (b) } \\
\text { Yokohama } \\
\text { port }\end{array}$ & $\begin{array}{c}\text { (c) } \\
\text { Kobe } \\
\text { port }\end{array}$ & (b)-(a) & (c)-(a) \\
\hline \multirow{3}{*}{$\begin{array}{l}\text { Domestic } \\
\text { flow in Korea }\end{array}$} & Trucking fees & $¥ 8.612$ & $¥ 8.612$ & $¥ 8.612$ & $¥-$ & $¥-$ \\
\hline & Customs fees & $¥ 11.913$ & $¥ 11.913$ & $¥ 11.913$ & $¥-$ & $¥-$ \\
\hline & Loading fees & $¥ 29.137$ & $¥ 29.137$ & $¥ 29.137$ & $¥-$ & $¥-$ \\
\hline $\begin{array}{l}\text { International } \\
\text { flow From } \\
\text { Busan and } \\
\text { Japan }\end{array}$ & (1) Sea frieght & $¥ 45.159$ & $¥ 73.544$ & $¥ 63.311$ & $¥ 28.385$ & $¥ 18.152$ \\
\hline \multirow{4}{*}{$\begin{array}{l}\text { Domestic } \\
\text { flow in Japan }\end{array}$} & $\begin{array}{l}\text { Unloading } \\
\text { fees from } \\
\text { ships }\end{array}$ & $¥ 147.450$ & $¥ 147.450$ & $¥ 147.450$ & $¥-$ & $¥-$ \\
\hline & $\begin{array}{l}\text { Customs } \\
\text { tariff }\end{array}$ & $¥ 24.950$ & $¥ 24.950$ & $¥ 24.950$ & $¥-$ & $¥-$ \\
\hline & $\begin{array}{l}\text { (2)Trucking } \\
\text { fees }\end{array}$ & $¥ 284.600$ & $¥ 175.000$ & $¥ 184.000$ & $¥-109.600$ & $¥-100.600$ \\
\hline & (3)Taxes & $¥ 7.316$ & $¥ 11.915$ & $¥ 10.256$ & $¥ 4.599$ & $¥ 2.940$ \\
\hline \multicolumn{2}{|l|}{ Total } & $¥ 559.137$ & $¥ 482.521$ & $¥ 479.629$ & $¥-76.616$ & $¥-79.508$ \\
\hline
\end{tabular}

Source: based on the author's interviews

The amount of resources needed to get to Yokohama and Kobe ports respectively can be estimated. In the case of using Yokohama port, transaction goods are shipped from Busan port on 6 Aug and expected to be unloaded on 10 Aug. All customs' procedures are estimated to finish on the 17th. It is on 18 and 19 Aug that all goods would have been delivered to Tokyo and Osaka respectively. We could assume that it takes approximately 13 days in total for goods to get to Tokyo and Osaka from Busan respectively. In the case of utilizing Kobe port, it would have taken one day less than using 
The Role of Interfirm Transactions on Cross Border Integration in East Asia: A Case Study of Interlinkages between Busan in Korea and Fukuoka in Japan

Yokohama port which gives us a total of about 12 days. In the research, the total amount of time shows that utilizing Shimonoseki port has a decisive advantage, like in the case of foods trading companies.

Next, we calculated the distribution costs of utilizing Shimonoseki port. Table 7 shows the total amount of distribution costs between actual and hypothetical distribution route. It took 559,137 JYP in total for both firms to distribute from Busan to Tokyo and Osaka. The differences between actual and hypothetical distribution costs were brought by the two major costs-factors as stated in the case of foods trading: Transport fees including international sea freight and trucking fee to destination from each port and incidental fees including the fees between custom tariffs and storage fees in custom bonded zone.

First, in the case of utilizing Shimonoseki port, "actual cost" took in total 337,075 JPY consisting of transport fees for international sea freight of 45,159 JPY, trucking fee of 284,600J PY and incidental fees of 7,316 JPY. On the other hand, when it was assumed for both to designate Yokohama and Kobe ports as the most proximate port from the distribution center, "hypothetical cost" could be estimated to take 260,459JPY in the case of Yokohama port and 257,567 JPY in Kobe port. The final difference accounted for $-76,616$ JPY in Yokohama port and -79,508 JPY in Kobe port respectively.

Consequently, it was not in the total distribution costs but in the total amount of time that Shimonoseki port could be confirmed to have obvious advantages. Even though the distribution cost of using Shimonoseki port was higher than other ports, both firms have been utilizing Shimonoseki port. It means that trading companies tend to give a priority to the total amount of time rather than the distribution costs.

\section{c. The factors for choosing particular port}

Through two case studies, the reasons why exporters in Busan have shipped to Shimonoseki port were clearly explored. Here, we analyze the factors that caused outstanding advantages of Shimonoseki port both in terms of distribution costs and total amount of time required to cover the distance from exporter's to importer's storages.

First, Shimonoseki port has advantages in the total amount of time due to the following factors: (1) Short time required for customs formalities and (2) Brevity of international shipping and (3) Convenient daily shipping schedules. 
According to interviews with firms, when they shipped to Shimonoseki port, it only took approximately 6 hours to unload fresh goods such as raw fish and a day or two to land other goods. On the other hand, in the ports located in Tokyo, Osaka and Nagoya metropolitan areas, it can be estimated to take 5 to 7 days on average to go through the customs. We also investigated how convenient it is for trading firms to use Shimonoseki port in terms of shipping schedules.

Table 8 displays the types of 30 Japanese ports that keep shipping schedules and offer regular sea freight services across ports in Korea. According to cluster analysis based on shipping schedules for a month, 30 Japanese ports can be classified into four types. Cluster A consists of Tokyo, Yokohama and Nagoya ports whose shipping schedules run on Tuesday and Saturday. It is named as "the type of ports in Tokyo and Ise Bay". Cluster B is composed of 22 local ports that have relatively much less frequent shipping schedules than others and we call it "the type of local ports". Cluster C is comprised of Kobe and Osaka ports that have mainly shipping schedules on Monday, Wednesday and Saturday. It is designated as "the type of ports in Kasai region". Finally, cluster D is made up of ports in Fukuoka region such as Shimonoseki, Hakata and Moji ports that don't give weight to specific days and have almost equal daily shipping schedules. We name it "the type of North Kyushu region".

As we have seen, it is clear that ports in Fukuoka are different from other types in terms of the shipping schedule. Especially, because of the fact that Shimonoseki port has daily shipping schedules from Busan port, the exporter can ship merchandise at any time that is convenient for them. It can persuade trading firms to use Shimonoseki port.

Next, we analyzed the advantage of distribution costs of Shimonoseki port in foods trading cases. Trading firms can use either insulated or refrigerated containers. However, their choice is influenced by the transport cost. When trading firms ship to Shimonoseki port, it takes a short time to embark on the journey that they tend to utilize insulated containers. When transporting to Yokohama port, they choose refrigerated containers.

In the case of using insulated containers, all goods, 13.5 tons of Manila clams, could be loaded in a 20 -foot-sized container. However, if they chose refrigerated containers, only 10 tons of goods could be loaded in a single container. In addition, individual refrigerated containers are not allowed to use the LCL shipping method which permits single containers to ship goods of multiple companies. Therefore, trading firms cannot help but utilize an extra 20 -foot-sized container for only 3.5 tons of goods. 
The Role of Interfirm Transactions on Cross Border Integration in East Asia: A Case Study of Interlinkages between Busan in Korea and Fukuoka in Japan

Table 8 - The classification of ports in Japan

\begin{tabular}{|c|c|c|c|c|c|c|c|c|c|}
\hline \multirow{2}{*}{ Clusters } & \multirow{2}{*}{ Ports } & \multicolumn{7}{|c|}{ Weekly shipping schedule } & \multirow{2}{*}{ Total } \\
\hline & & Mon & Tue & Wed & Thu & Fri & Sat & Sun & \\
\hline \multirow{3}{*}{ Cluster A } & Tokyo & - & 3 & - & 1 & 1 & 3 & - & 8 \\
\hline & Yokohama & - & 4 & - & 2 & 1 & 3 & 2 & 12 \\
\hline & Nagoya & - & 3 & - & 1 & 2 & 3 & 1 & 10 \\
\hline \multirow{2}{*}{ Cluster C } & Osaka & 5 & - & 4 & - & 1 & 5 & - & 15 \\
\hline & Kobe & 6 & - & 4 & - & 1 & 5 & - & 16 \\
\hline \multirow{3}{*}{ Cluster D } & Shimonoseki & 2 & 2 & 2 & 2 & 1 & 1 & 2 & 12 \\
\hline & Moji & 3 & 1 & 2 & 3 & - & - & 2 & 11 \\
\hline & Hakata & 1 & 2 & 1 & 1 & 1 & - & 2 & 8 \\
\hline \multirow{22}{*}{ Cluster B } & Hiroshima & 1 & - & 1 & 1 & - & 2 & - & 5 \\
\hline & Niigata & 2 & - & 1 & - & 1 & 1 & - & 5 \\
\hline & Kanazawa & 1 & - & - & - & 1 & 1 & - & 3 \\
\hline & Tsuruga & 1 & - & - & - & - & 1 & 1 & 3 \\
\hline & Mastuyama & 2 & - & - & 1 & - & - & - & 3 \\
\hline & Tokushima & - & 1 & - & 1 & - & - & 1 & 3 \\
\hline & Tomagomai & - & - & 1 & - & - & - & 2 & 3 \\
\hline & Nakanoseki & - & 1 & - & 1 & - & - & 1 & 3 \\
\hline & Hososhima & 1 & 1 & 1 & - & - & - & - & 3 \\
\hline & Tokuyamashin & 2 & - & - & - & 1 & - & - & 3 \\
\hline & Yokkaichi & - & - & - & - & 1 & 1 & - & 2 \\
\hline & Wakayama & - & - & - & - & - & 2 & - & 2 \\
\hline & Tokuyama & - & - & - & 1 & - & 1 & - & 2 \\
\hline & Maizuru & - & - & - & - & - & 1 & 1 & 2 \\
\hline & Chiba & - & 1 & - & - & - & 1 & - & 2 \\
\hline & Akita & - & - & - & - & - & - & 1 & 1 \\
\hline & Sakata & - & - & - & - & - & - & 1 & 1 \\
\hline & Naoetsu & - & - & - & - & 1 & - & - & 1 \\
\hline & Mizushima & - & - & - & - & - & 1 & - & 1 \\
\hline & Sakaikou & - & - & - & - & - & - & 1 & 1 \\
\hline & Imabari & 1 & - & - & - & - & - & - & 1 \\
\hline & Oita & - & - & - & - & - & - & 1 & 1 \\
\hline \multicolumn{2}{|l|}{ Total } & 28 & 19 & 17 & 15 & 13 & 32 & 19 & 143 \\
\hline
\end{tabular}

Source: based on "The weekly Shipping Gazette 44-51" (Korean) 
Lastly, so as to explore the reason why exporters and importers would trade special apparel goods while observing the total amount of time rather than distribution costs, we tried to interpret the trends based on the 2 following factors: (1) the percentage of transport costs per total amount of exports and (2) the relation between the period of delivery and total amount of sales in shops.

Table 9 shows the relation between the total amount of transactions and the percentage of transportation costs in each port in Japan. According to the transport cost for the total amount of transactions, Shimonoseki port accounts for 3.7\% while Yokohama and Kobe ports take shares of $2.8 \%$ and $2.5 \%$ respectively. In other words, the disparity among Shimonoseki, Yokohama and Kobe ports is about $1 \%$. It is also clear that even though it takes more transportation costs to use Shimonoseki port rather than others, trading firms don't mind the loss of $1 \%$ on transportation costs and tend to give priorities to the total amount of time in which firms can distribute the goods; the shortest delivery takes 8 days.

Table 9 - Transportation costs concerning with the transaction price

\begin{tabular}{|l|c|c|}
\hline Ports & Transaction costs & $\begin{array}{c}\text { Transportation costs concerning with } \\
\text { the transaction price(\%) }\end{array}$ \\
\hline Shimonoseki port & 337.075 & $3,7 \%$ \\
\hline Yokohama port & 253.959 & $2,8 \%$ \\
\hline Kobe port & 227.567 & $2,5 \%$ \\
\hline Transaction cost & 9.114 .493 & $/$ \\
\hline
\end{tabular}

Source: based on the author's interviews

Table 10 indicates the selling period of transported goods at 10 shops of T department stores. 95 pieces of women's apparel were distributed to T department stores; 53 pieces out of those 95 were sold out completely. After being delivered to shops, 35 pieces of them were sold in the first and second weeks; it accounts for $66 \%$ of the total sales. It is remarkable that the amount of sales is extremely high and concentrated in the first 2 weeks. Company A assumes every single item to be sold in the period between 30 and 45 days. Considering that the sales period of A coincides with those of business rivals with similar kinds of goods ${ }^{8}$. As long as transportation costs do not rise up

\footnotetext{
${ }^{8}$ The meaning of 8 to 10 days can be more significant for Company A.
} 
The Role of Interfirm Transactions on Cross Border Integration in East Asia: A Case Study of Interlinkages between Busan in Korea and Fukuoka in Japan

significantly, trading firms tend to choose a port that enables the commodities to be delivered in the shortest time. Customs duty tends to be imposed on the transaction cost including sea freight cost. Therefore, trading firms decide to choose cheaper shipping cost by sea freight than by trucking service.

Table 10 - The sales amount of women's apparel in T department stores

\begin{tabular}{|l|c|c|c|c|c|c|c|}
\hline Stores & $\begin{array}{c}\text { Stocks } \\
\text { (single } \\
\text { item) }\end{array}$ & $\begin{array}{c}\text { Sales } \\
\text { amount } \\
(\mathbf{s i n g l e} \\
\text { item) }\end{array}$ & $\begin{array}{c}\mathbf{1}^{\text {st }} \\
\text { week }\end{array}$ & $\begin{array}{c}\mathbf{2}^{\text {nd }} \\
\text { week }\end{array}$ & $\begin{array}{c}\mathbf{3}^{\text {rd }} \\
\text { week }\end{array}$ & $\begin{array}{c}\mathbf{4}^{\text {th }} \\
\text { week }\end{array}$ & $\begin{array}{c}\text { After }^{\text {th }} \\
\text { week }\end{array}$ \\
\hline Ikebukuoro & 17 & 10 & 1 & 7 & 2 & 0 & 0 \\
\hline Dokorozawa & 8 & 7 & 1 & 5 & 1 & 0 & 0 \\
\hline Kawasaki & 11 & 6 & 3 & 1 & 0 & 1 & 1 \\
\hline Funabashi & 9 & 8 & 2 & 2 & 0 & 2 & 2 \\
\hline Tsukuba & 9 & 5 & 1 & 2 & 0 & 1 & 1 \\
\hline Utsunomiya & 7 & 5 & 2 & 2 & 0 & 0 & 1 \\
\hline Tsukashin & 10 & 3 & 1 & 1 & 0 & 1 & 0 \\
\hline Darumaya & 8 & 6 & 2 & 1 & 0 & 0 & 3 \\
\hline Hakotate & 8 & 3 & 1 & 0 & 0 & 0 & 2 \\
\hline Komatsu & 8 & 0 & 0 & 0 & 0 & 0 & 0 \\
\hline Total & 95 & 53 & 14 & 21 & 3 & 5 & 10 \\
\hline (\%) & & 100 & $26,4 \%$ & $39,6 \%$ & $5,7 \%$ & $9,4 \%$ & $18,9 \%$ \\
\hline
\end{tabular}

Source: The author's interviews

Finally, we investigated the reasons why most of firms utilize ports rather than airports. It is rare for trading firms to distribute to Japan by air; this only happens a few times in a year. It is limited in the moments when (1) an exporter sends sample items that require shortest delivery time and (2) an exporter is expected to make it on time specified in contracts to deliver goods. 
Table 11 - The cost of the means of transporation

\begin{tabular}{|c|c|c|c|c|c|c|c|}
\hline \multirow{2}{*}{$\begin{array}{l}\text { Transac- } \\
\text { tion goods }\end{array}$} & \multirow{2}{*}{$\begin{array}{l}\text { Shipping } \\
\text { Date }\end{array}$} & \multirow{2}{*}{$\begin{array}{c}\text { Weight } \\
\text { (kg) }\end{array}$} & \multirow{2}{*}{$\begin{array}{l}\text { Unit } \\
\text { (US\$) }\end{array}$} & \multicolumn{2}{|c|}{$\begin{array}{c}\text { Transaction cost } \\
\text { (US\$) }\end{array}$} & \multirow{2}{*}{$\begin{array}{c}\text { (3) } \\
\begin{array}{c}\text { Transporta- } \\
\text { tion costs }\end{array} \\
(1)-(2)\end{array}$} & \multirow{2}{*}{\begin{tabular}{|c}
$\begin{array}{c}\text { Ratio of } \\
\text { transporta- } \\
\text { tion }\end{array}$ \\
$(3) /(2)$
\end{tabular}} \\
\hline & & & & $\begin{array}{l}(1) \\
\text { C.I.F* }\end{array}$ & $\begin{array}{c}\text { (2) } \\
\text { F.O.B }\end{array}$ & & \\
\hline \multicolumn{8}{|c|}{ Shimonoseki port } \\
\hline \multirow{6}{*}{ Ark shell } & 25-Mar-15 & 500 & 23,00 & 11.500 & 11.276 & 224 & $1,95 \%$ \\
\hline & 8-Apr-15 & 1.120 & 22,32 & 25.000 & 24.509 & 491 & $1,96 \%$ \\
\hline & 29-Sep-15 & 2.100 & 22,33 & 46.895 & 45.971 & 924 & $1,97 \%$ \\
\hline & 20-Oct-15 & 4.300 & 19,14 & 82.300 & 80.676 & 1.624 & $1,97 \%$ \\
\hline & 1-Nov-15 & 3.500 & 22,64 & 79.250 & 77.684 & 1.566 & $1,98 \%$ \\
\hline & 24-Nov-15 & 2.700 & 22,39 & 60.450 & 59.257 & 1.193 & $1,97 \%$ \\
\hline \multicolumn{8}{|c|}{ Sendai airport } \\
\hline Giant clam & 5-Sep-15 & 75 & 7,00 & 525 & 348 & 177 & $50,86 \%$ \\
\hline
\end{tabular}

Source: The author's interviews

Table 11 displays the transport cost of blood clam shipped to Shimonoseki port and giant clam to Sendai airport. Transport cost per transaction cost occupied about $2 \%$ in the case of using sea fright, while it accounted for approximately $51 \%$ in the case of using air flight. Transaction product unit cost for foods and apparels is so low that trading firms utilize ports rather than airports and choose the distribution route that enabled the goods to be delivered to the distribution centers within the shortest time.

\section{Conclusion}

Since the period of 1980s, many small and medium sized exporters with head offices located in Busan have operated their own international sales networks with Japanese clients. In the process of international trading 
The Role of Interfirm Transactions on Cross Border Integration in East Asia: A Case Study of Interlinkages between Busan in Korea and Fukuoka in Japan

business, they have set up inter-urban linkages mainly in three metropolitan regions (Tokyo, Osaka and Nagoya) as well as Fukuoka. The inter-urban linkages created by international trade have in turn molded the structure of international urban system between Korea and Japan.

International trade activities of firms in Busan are very complex unlike other businesses on the national level. In addition, they are characterized by sales channels, business trips and shipping of goods that are long and split among various spatial levels. Moreover, the destination of sales channels, business trips and shipping of goods make a significant difference to the pattern of inter-urban linkages based on international transaction. As a result, it is impossible to examine inter-urban linkages in adequate detail using conventional published sources and the reports of government agencies.

The present research is based on data tabulated by the author from the original questionnaire, relying on the directory of 62 different types of exporters in Busan. In the process, international trade activities of exporters were classified into 3 aspects according to their designated level of the business affairs' details, such as sales channel, business trip and shipping of goods; we named them "Transaction", "Business trip" and "Physical distribution". Analyzing the spatial structure of physical distributions, we discovered the reason why Shimonoseki port have been utilized as a gateway for business trip and physical distribution and have the decisive advantage compared to others in Japan.

In the case study, we selected two transaction cases in food and apparel businesses. We also (1) tried to track which routes the transaction of goods took for the delivery of goods to and from their distribution center and (2) clarified the total amount of time and distribution costs in taking actual and hypothetical distribution routes.

In the food trading cases, the advantage of using Shimonoseki Port is not only the total amount of time but also the distribution costs of shipping goods from exporter in Busan to importer's distribution centers in Japan. In the apparel trading cases, however, only the total amount of time consumed from the initial location in Busan to the destination in Japan contributed to giving the decisive advantage to Shimonoseki port. The reasons why Shimonoseki port has advantage in the total amount of time are due to the 3 following factors: (1) short time required by customs formalities, (2) brevity of international shipping time and (3) convenient daily shipping schedules.

If we look at international urban system between Korea and Japan in context of international trade activity, and in particular at the non-capital 
and non-metropolitan regions that lie at the periphery of that system such as Fukuoka, we can find even more different patterns of inter-urban linkage. The linkage between Busan and Fukuoka mainly sits at the apex of the international urban system from the perspective of the gateway of shipping of goods and business trip, whereas links to Tokyo and Osaka mostly act as transactional and functional core such as sales channels.

Regarding the international trade activities between Fukuoka and three metropolitan cities, obvious different relationships can be detected in the pattern of inter-urban linkages in the respective international function such as physical distribution, sales and business channels. The result leads us to draw the conclusion that the development of inter-linkages between non-capitals, for instance Fukuoka and Busan, can reinforce peripheral cities to diversify their urban functions and it eventually can be one of vitalizations of regional internationalization.

\section{Acknowledgements}

We are grateful to experts for their appropriate and constructive suggestions to improve this article. This work was supported by the Korean Federation of Science and Technology Societies (KOFST) grant funded by the Korean government (MSIP: Ministry of Science, ICT and Future Planning) and Fund for the Promotion of Joint International Research funded by Japan Society for the Promotion of Science (JSPS).

\section{References}

Abe K, 2005. The evolution of the Korean urban system from the standpoint of large private firms' head and branch offices: 1985-2002. The Geography Reports 101:1-10. (in Japanese)

Abe K, 2009. Major cities and urban systems of France from the standpoint of large private firms' head and branch offices. Bulletin of Aichi University of Education 58:133-140. (in Japanese)

Abe K, 2010. The urban system from the standpoint of large private firms' head and branch offices. The Geographical Reports 115:1-10. (in Japanese)

Abe K, 2014. Status of Tokyo. Journal of Geography 123: 315-322. (in Japanese) 
The Role of Interfirm Transactions on Cross Border Integration in East Asia: A Case Study of Interlinkages between Busan in Korea and Fukuoka in Japan

Dimitov D. 2016. Factors for the Economic Marginalization of the Northwestern Statistical Region and Tools for its Overcoming, Zbornik radova Geografskog fakulteta 64: 131-132.

Georgieva V. 2016. CBC Programmes Impact in Northwest NUTS II Region of Bulgaria in the Period 2007-2013, Zbornik radova Geografskog fakulteta 64: 146-156.

Kitada K, 2000. Spatial Structure of Urban System in Korea in Terms of Intercity Passenger Flows. Journal of Geography 109: 106-119. (in Japanese)

Morikawa H, 1997. The Modernizing Process of Urban Functions and Urban Systems from the End of Edo Period to the Period before World War II. Journal of Geography 106: 10-30. (in Japanese)

Murayama Y., 1982. Diffusion Channels of Innovation in the Urban Systems. Annals of The Tohoku Geographical Association 34: 224-235. (in Japanese)

Murayama Y., 1994. City Systems Research-Outcomes and Issues. Japanese Journal of Human Geography 46: 44-65. (in Japanese)

Nishihara J, 1991. The Development of Intra-Corporate Branch Networks and the Japanese Urban System. Geographical Review of Japan. Ser. A 64: 1-25. (in Japanese)

Park J., 1997. The International Urban System between Korea and Japan in Terms of Transactions of Korean Banks with Japan. Geographical Review of Japan. Ser. A 70: 661-675. (in Japanese)

Park J., 1998. The International Urban System between Korea and Japan in Terms of International Telephone Calls. Geographical Review of Japan. Ser. A 71: 600-614.

Park J., 2002. International Urban System in Asia. Tokyo: Kokonshoin. (in Japanese)

Park J, and Fujimura M. 2016. The Initiatives of Cross Border Cooperation in Automobile Parts Industry between Busan and Fukuoka. International Journal of Accounting \& Business Management 4:87-97.

Sugiura Y, 1978. Innovation Diffusion and Urban System in Japan during the Meiji and Taisho Era, 1868-1926. Geographical Report of Tokyo Metropolitan University 13: 29-48. (in Japanese)

Sugiura Y, 1997. Spatial diffusion of electric power looms in the Fukui silk Weaving industry, modern Japan. Japanese Journal of Human Geography 49: 419-441. (in Japanese) 